\title{
THE ORIGINS OF INDUSTRIAL CONCILIATION AND ARBITRATION ${ }^{1}$
}

\author{
THE RELATIONSHIP PATTERN
}

Trade unionism has always involved the settlement of industrial disputes by negotiations between workers' representatives and employers. On occasions in the eighteenth and first half of the nineteenth centuries demands made by workers or employers were granted without question by the other side; at other times the demands were rejected out of hand and this was acquiesced in by the other side. In between these extremes lay a number of possible outcomes. Demands were sometimes conceded after strikes or lockouts or they were moderated and then accepted. The precise outcome depended upon the state of the labour market, and hence the degree of labour organization, and the cost position of the employers. These factors not only varied over time but differed in their intensity between industries and firms at any one point of time. The extreme situations occurred at high and low levels of employment. In the competition for labour, which a high level of employment implies, employers readily gave way to collective demands but as commodity markets deteriorated and the volume of production declined, they at first resisted claims which would have increased labour costs and then deliberately set out to cut wages, lengthen hours and intensify work. Workers commonly resisted initial attempts to reduce labour costs so that a spate of strikes and lockouts ensued. At the onset of the depression in 1819 and at the first suggestion of wage reductions the Lancashire miners, the North Staffordshire potters and the Nottingham framework knitters all responded by striking. The Glasgow cotton spinners resisted wage cuts in 1837 as did the London building workers and miners and textile workers in the midlands and north in $184 \mathrm{I}$ and the typographical workers in 1846. Frequently, however, these disputes resulted in

1 This paper was originally read to a meeting of the Labour History Group in Leeds on 9th October I963. I am grateful to Dr. J. E. Williams who discussed the subject of the paper with me throughout my work on it and who read and criticized it in draft form. 
compromise settlements which were superseded by other compromises as trade conditions got worse.

The ability of workers to engage in industrial action depended largely upon the condition of their union organizations. Union membership declined with the level of employment so that at the trough of a trade depression the ability of workers to resist was also at its lowest point. In the upward trade movement from the trough workers in various industrial groups tried to regain their former wages and initiated strike movements for this purpose. Building workers in Manchester took advantage of the brief improvement in trade in 1818 to strike for wage increases and were followed by dyers, cotton spinners, power-loom weavers and hand-loom weavers from various parts of Lancashire. A revival in trade in 1825 stimulated the long and bitter strike of Bradford woolcombers and weavers and a strike of clay potters in North Staffordshire. The National Association for the Protection of Labour and the General Union of Spinners both emerged from agitations for wage increases in 1829 as trade began to improve. In 1833 trade recovery resulted in widespread trade union activity, particularly among building workers. Strike action marked the movement away from depression after 1842 . In these cases too compromise settlements were often reached until the point at which the willingness of employers to resist was at its weakest, namely when there was full or over-full employment.

In so far then as there was a pattern of industrial action up till r 860 , it took this shape. The action had some marked characteristics. Notice of intended or desired changes was sometimes given in writing. Employers posted notices in their works, workers put notices in the press or submitted them by letter. Usually, date lines were given after which strikes or lockouts were enforced. In some cases workers gave notice of their intentions by striking. Wherever resistance to a demand was met there would be immediate strike or lockout action. In a few trades such as printing and bookbinding it was the practice for workers' representatives and employers to meet before industrial action was taken but usually discussions followed such action. In all trades, however, employers and workers representatives met only when issues arose which threatened to disrupt production. They did not anticipate disruption.

After the French Revolution had lost its immediate significance for Britain industrial disputes were largely regarded as the private affairs of employers but occasionally it was suggested that employers should countenance a form of outside interference. The Government attempted to influence the determination of disputes through the 
Arbitration Act in 1824, after the repeal of the Combination Acts. The Act excluded the determination of wages unless the mutual consent of both parties was obtained; it made arbitration compulsory and contained penal provisions. The intention of its draughtsmen was to displace voluntary settlements. The Act was amended in 1837 and I 845 but it was never applied. There were advocates of a permanent system of arbitration along lines suggested by the French conseils des prud'bommes formed after $\mathrm{I} 806$. William Felkin, the Nottingham lace manufacturer, was the most prominent early advocate. In 1834 he translated into English an account of the conseils des prud'bommes and ten years later read a paper on boards of conciliation before the British Association. ${ }^{1}$ Under Felkin's influence the largest hosiery union petitioned Parliament in 1845 for the establishment of Courts of Conciliation and Arbitration. ${ }^{2}$ The National Association for the Promotion of Social Science became a forum for advocates of conciliation and arbitration after its formation in 1857 . The writer of a paper on the 1858 West Yorkshire coal strike, read at the 1859 meeting of the Association, suggested that Courts of Arbitration would be a fitting and proper mode of settling industrial disputes. ${ }^{3}$ The subject gradually became a popular one for intellectual sympathisers of trade unions to argue.

The advocacy made little impression before i 860. The Glasgow and Risley textile employers and operatives established an annual conference in 1834 to revise prices for the ensuing year; in the same year an arbitration committee was formed by the Staffordshire potters; three boards of arbitration were formed in the i 850 , in the Macclesfield silk trade, the wooden shipbuilding industry, the London printing trade. ${ }^{4}$ None of the experiments, however, was successful; all were short-lived for reasons associated with their immediate environments. In printing, for instance a permanent joint Arbitration Committee was established in 18,6 . Three journeymen sat with three employers under the chairmanship of a barrister with a casting vote. The union and employers stated that the Committee would "serve for the amicable settlement of all Disputes which may hereafter arise relative to the Prices to be charged and paid for Work, without incurring the expense, trouble and irritation consequent upon an

1W. H. G. Armytage, A. J. Mundella 1825-1 897. The Liberal Background to the Labour Movement, p. 33 .

2 William Felkin, A History of the Machine Wrought Hosiery and Lace Manufacture, London 1867 , p. 47 I.

3 Transactions of the National Association for the Promotion of Social Science, 1859, p. 653.

${ }^{4}$ I. G. Sharp, Industrial Conciliation and Arbitration in Great Britain, pp. I-2. 
appeal to a Court of Law". ${ }^{1}$ The Committee settled minor differences satisfactorily but the first important dispute, submitted nine months after the Committee's formation, had to be solved by litigation. ${ }^{2}$ The Committee did not survive this failure. Then in 1860 a standing committee for regulating the relations between employers and workers in the Nottingham hosiery trade was formed. This had an immediate public impact but nothing else like it was formed until i 864 when an arbitration board for the building trades in Wolverhampton was established.

Thereafter the number of conciliation and arbitration bodies increased. The Nottingham Chamber of Commerce convened a board for the lace trade in 1867 ; by the following year standing committees of one kind or another were operating in the hosiery trade in Leicester, the Staffordshire pottery trade, the glass bottle industry, and the building industry in Leeds, Manchester, Coventry and Worcester. The Board of Arbitration and Conciliation for the Manufactured Iron Trade of the North of England was formed in 1869 . The number of industries covered by joint committees or boards increased in the first half of the I $870 \mathrm{~s}$. In addition arbitration, without the existence of standing provisions, became popular. A recognized group of arbitrators emerged consisting largely of A. J. Mundella, M.P., Judge Rupert Kettle, Thomas Hughes, Q. C., Henry Crompton, Lloyd Jones and a small group of lesser known men, mainly barristers. These sometimes intervened on their own initiative; at other times they were invited to intervene. Such was the climate of opinion about arbitration that almost any public figure could offer his services as an arbitrator without offending the parties involved. In I 874 the Bishop of Manchester arbitrated in a Manchester building dispute, and heard the parties in his residence. ${ }^{3}$ During a six weeks strike in Dundee in I 875 a local solicitor intervened and brought the parties together. ${ }^{4}$ By 1875 there was barely a trade where trade unions existed which did not have either a standing joint committee of employers and workmen to settle disputes, with provision for arbitration, or the experience of settling disputes through arbitration on an ad hoc basis. There was, as the editor of Capital and Labour pointed out in October, I 875, an "arbitration craze".5 To round the craze off a National Conciliation League was formed in December, 1875, to foster the principle of arbitration.

1 The London Compositor, 1785 -1900, edited by Ellic Howe, p. 266.

2 Ibid., p. 248.

${ }^{3}$ Capital and Labour, April, 1874 , p. 106.

4 Ibid., September 1875 , p. 496.

5 Ibid., 27th October 1875, p. 62 I. 
There were boards of arbitration and conciliation, of arbitration alone and conciliation alone but regardless of the nomenclature they frequently functioned as joint negotiating committees consisting of equal numbers of employers and workers' representatives. They had written constitutions with provisions to specify their composition, regulate the timing of their meetings and to stipulate their powers. Thus they constituted a systematic, orderly method for dealing with industrial disputes which formed the framework for a system of collective bargaining. Mostly provisions were made for removing deadlock; a chairman was given a casting vote, or a referee was provided for, or assessors from each side sat with an independent arbitrator. It was not necessary, however, for a constitution of a board to contain arbitration provisions for arbitration to be used. Whilst the institution of collective bargaining procedures was a radical departure from past practices, the acceptance of arbitration by employers was even more remarkable for it was an acknowledgement that independent persons could sit in judgement on what hitherto had been regarded as the private preserve of employers. Why in the two decades following I 860 did these changes occur?

THE NECESSARY CONDITIONS

The necessary conditions for the existence of both conciliation and arbitration were present before $\mathrm{I} 860$. Both trade unions and employers in some trades were sufficiently well organized and in charge of their affairs to be able to meet and reach decisions about their relationship and to enforce those decisions. Trade unions in some trades, such as engineering, printing, bookbinding and building, were wellestablished and relatively effectively organized. The fact that most unions were not centrally organized was not important for action could still be taken at a district or local level. In their respective spheres of influence union officials were capable of negotiating regularly on behalf of their members for that indeed is what they did but in an ad boc manner. There was no ideological reason in the way of their wanting to establish regular relationships with employers. An increasing number in I840s and I850s were becoming full-time and desired to make their positions permanent. They tried to centralize union affairs and this involved curtailing the strike activities of branches. The accumulation of union funds was also dependent upon a reduction in local strikes. Any move, therefore, which assisted union officials in this direction would have been welcomed. As for employers, there were no institutional reasons in the way either of their membership of standing joint committees or of their accepting arbitration. 
There was relatively little permanent collusion between employers but they were capable of acting together as they had shown through the enforcement of numerous lockouts as retaliatory measures. Some employers were sufficiently large to be able to act unilaterally over negotiating machinery. Nor was trade union recognition a problem.

It is not possible to estimate the extent to which unions were recognized by employers in the two decades prior to 1860 but in the majority of trades where unions were strong enough to engage in disputes at some stage they usually had to be given de facto recognition by employers. Employers, however, resisted conceding permanent recognition to trade unions which the creation of standing conciliation machinery would have involved. There was a strong reluctance to regard unions as established sections of industry - they were treated always as if they could be suppressed either by the lock-out and the document or by law and, in the main, employers behaved as if they were anticipating suppression. The degree of recognition accorded to unions depended upon their ability to force their attention upon employers; that is upon their actual or potential strike power in relation to the market position of the employers. Because of frequent and intensive changes in the state of trade and level of employment the power of unions varied too so that an employer's assessment of a union was never constant for long; nor, therefore, was his desire to maintain conciliatory relations with it. The attitude of employers towards arbitration was typified by the reaction of the Preston textile employers in 1854 , when, during a trade dispute, a group of middleclass residents offered to mediate. Wages, the employers asserted, had to be left to the "free operation of supply and demand". To accept mediation, they added, would be to acknowledge "a principle, most dangerous and mischievous in its tendency - a principle alike subversive of the rights of the working man in the disposal of his labour, and of the rights of the master in the employment of his capital". 1

Both attitudes persisted throughout the nineteenth century and into the twentieth. Permanent negotiating machinery was not widely established until after the first world war; and as late as 1897 an employer informed the Government that his acceptance of a Board of Trade mediator would "establish a precedent for outside interference with the management of my private affairs". ${ }^{2}$ But from I 860 the attitudes of some employers altered sufficiently to allow for the growth of permanent machinery and arbitration provisions.

1 The National Association for the Promotion of Social Science, Trades' Societies and Strikes, r 860, p. 245.

2 Lord Penrhyn to the President of the Board of Trade; see V. L. Allen, Trade Unions and the Government, p.!5 2. 
A common explanation by contemporary participants and observers of the rise of conciliation and arbitration was that after decades of bitter conflict reason was being applied to industrial relations. Prior to 1860 , wrote Henry Crompton in 1876 , "the history of the relations between employers and employed in the [hosiery] trade is that of war. If the worst aspects of this war, the terrible riots, the murders, arsons, and machine-breakings of the early part of the century, had disappeared, there was still hatred and suspicion by the operatives towards their masters, who in turn entertained feelings of animosity against the men... the change has been from war to peace. Confidence and good will have replaced suspicion and open hostility". ${ }^{1}$ A. J. Mundella, in I 868 , stated that the "want of some connecting link betwixt masters and workmen - some arrangement for the friendly bargain and sale of labour - has resulted in those dreadful strikes and lock-outs which have disgraced our age and country". ${ }^{2}$ In a debate on the merits of conciliation and arbitration at the National Association for the Promotion of Social Science in 1868 opinion almost unanimously regarded conciliation and arbitration as means of removing industrial conflict. ${ }^{3}$ This contention appeared to be substantiated by the reduction in the number of official strikes in trades where conciliation and arbitration were practiced. In the mid-I 870 s the employer members of the North of England iron trades board stated that "The Board has been in operation since 1869 , and during the whole of the intervening period the general district wage regulations have been settled without resort to strikes or lockouts..."4 Similar claims were made for the Nottingham hosiery trade, the North Eastern coalmining industry, and the Midland building industry. ${ }^{5}$

\section{COMMON CHARACTERISTICS}

The circumstances surrounding the establishment of a number of boards in the 1860 s possessed common characteristics. The Nottingham hosiery trade was in a state of stagnation for about 30 years until the 18 sos when technological improvements were introduced. During that period the hosiery workers were "forced to acquiesce in whatever conditions might be offered". 6 In the late I850s there was renewed

${ }^{1}$ Henry Crompton, Industrial Conciliation, pp. 33-34 and 48.

2 Transactions of the National Association for the Promotion of Social Science, I868,

p. 525 .

3 Ibid., pp. 579-592.

4 Crompton, op. cit., p. 59.

${ }^{5}$ E. H. Phelps Brown reiterates these claims in The Growth of British Industrial Relations, p. 126.

${ }^{B}$ F. A. Wells, The British Hosiery Trade, p. 160. 
activity by the hosiery unions which endeavoured to exploit the expanding trade and increasing demand for labour. The most prosperous section of the trade was machine production and a widening disparity between the earnings of machine and hand workers occurred. ${ }^{1}$ The hand workers, therefore, had most reason to be disgruntled; they did not receive automatic benefits from a favourable market situation so they called a number of strikes. In 1860 there were three strikes in the wide-frame branch of the trade, one of which lasted for I I weeks. Such was the demand for hosiery, however, that the manufacturers depended upon production in all the branches of the trade to satisfy it. The strikes prevented the manufacturers from meeting "the heavy demands of the American trade", 2 but at the same time they were not prepared to grant wage increases. As Felkin put it: "the workmen struck for an advance of wages which the employers believed it would be impolitic to grant". ${ }^{3}$ The strikers were supported by workers in employment so the dispute concerned the whole of the trade and some employers wanted to retaliate by using the lock-out. They could have done so uniformly because, in r 860, they had united in both a Hosiers' Association and the Nottingham Chamber of Commerce.

Thus in a situation where both the traditional lockout and the continuation of the strike were economically undesirable any course which held down labour costs without interrupting production was to be preferred. Given the existence of employers' and workers' organizations a rational way seemed to be to obtain the support of workers for steps to make the industry competitive with Continental producers - that is to withhold from making excessive demands or from stopping production. This way was pointed to by A. J. Mundella, a manufacturer, who supported the ideas of Felkin. He advised his fellow employers to meet the operatives in conference. ${ }^{4}$ The advice was accepted and on 2 Ist September a joint statement was issued which stated that: "It is further agreed, that in order to prevent a recurrence of strikes which have been so disastrous to employers and employed, a Board of Arbitration be at once formed..." 5

Mundella's case for conciliation was in effect an argument for moderation. He spoke of the need to consider the interests of the trade and maintained that because of competition from Germany it was

\footnotetext{
${ }^{1}$ Cf. Roy Church, Technological Change and the Hosiery Board, in: Yorkshire Bulletin of Economic and Social Research, Vol. I 5 , No. $x$, May I 963, p. 53.

2 Wells, op.cit., p. 160.

${ }^{3}$ Felkin, op.cit., p. 484.

Armytage, op.cit., p. 32.

Nottingham Review, 2 Ist September I860, p. 5.
} 
impossible for the trade to pay higher wages. He even offered to pay the passage for a workers' delegation to Germany to investigate the extent of German competition. This appeal for reason took place against the background of an expanding market and a high level of employment.

In Nottingham at the same time, the lace trade was also experiencing continental competition, mainly from France, but the market was not expanding with the consequence that the Nottingham trade was contracting. ${ }^{1}$ The lace manufacturers, like the hosiers, wanted to cut their labour costs and because the labour market favoured buyers they were in a position to do so unilaterally. They imposed wage cuts and locked out the employees who would not accept them for three months, endeavouring in the process to break up the unions. ${ }^{2}$ The Nottingham hosiery and lace manufacturers both belonged to the Nottingham Chamber of Commerce which had been formed to counter the effects of foreign competition, yet their responses were entirely different. The Chamber of Commerce supported conciliation and arbitration in hosiery but refrained from intervening in the lace trade. The main variable in the situation was the level of employment and indirectly the strength of the trade unions. The variable differed in its impact in the two trades and evoked opposite responses. When, however, the lace trade was moving out of a state of depression after the mid-r86os and the employment situation was becoming more difficult for employers they both formed their own association and, in 1867 , established a Board of Arbitration for the Nottingham Machine-Lace Trade. The Chamber of Commerce undertook the task of constituting the Board when Mundella was its president. A factor which undoubtedly influenced the lace manufacturers was the apparent success of the Hosiery Board in quietening the unions.

A. J. Mundella was joined at an early stage in his self-appointed task of propagating the idea of conciliation and arbitration by Rupert Kettle, Judge of the Wolverhampton County Court. Kettle concentrated on the Midlands area and had most effect in the building trade. In 1864 he participated in a court of arbitration for carpenters and joiners in Wolverhampton. The situation in all essentials was similar to that which had existed in the hosiery trade. From I86I to 1863 the number of houses built each year rose from 45,200 to $64,400 .^{3}$ The number remained high, at 60,900 in 1864 , then it fell sharply. In 1863

${ }^{1}$ In the 3 years ending June, I 860, 57 lace houses went bankrupt; Norman H. Cuthbert, The Lace Makers' Society, p. 4 In.

2 Ibid., p. 42.

${ }^{3}$ B. R. Mitchell and Phyllis Deane, Abstract of British Historical Statistics, p. 239. 
and 1864 there was, therefore, a high demand for labour and the building unions used the occasion to strike for higher wages. In I 864 one strike in Wolverhampton lasted about 17 weeks. It ended with an uneasy settlement which the Mayor of Wolverhampton thought would be followed by another strike so he called a public meeting. From this meeting an arbitration court with Judge Kettle as its chairman was formed. The building workers, instead of exploiting this market situation, were prevailed upon "to take a gradual rise in wages". ${ }^{1}$ Thus the experience of the hosiery board was repeated. The Working Men's Club, of which Kettle was president, asked him to assist with establishing conciliation and arbitration courts in other towns and as a result the building industry in Coventry, Worcester, Leeds, Manchester and Salford had courts by 1868 . But these too were established in a rising market for labour for the industry moved out of its depression after 1864 . When the Royal Commission on Trade Unions sat in 1 867-68 conciliation and arbitration were seriously examined on the basis of papers by Mundella and Kettle.

The boards were also a subject for discussion by trade unions. At the conference of the United Kingdom Alliance of Organized Trades in Sheffield in 1866 George Odger raised the subject and condemned strike action. The conference advocated the establishment of councils of arbitration and conciliation. Both Mundella and Kettle pressed their advocacy to the point of offering their services as mediators or arbitrators in disputes. One such occasion occurred in 1868 in South Lancashire when the coal miners struck against an employer's attempt to impose a wage reduction of is per cent. ${ }^{2}$ The strike lasted from March until May and was marked by almost continual violence because of the determined use of blacklegs. After about a month, A. J. Mundella wrote in his capacity as president of the Nottingham Chamber of Commerce to the Mayor of Wigan suggesting that he should give "a lecture advocating the establishment of a Court of Arbitration and Conciliation in Wigan". The Court, he suggested, should consist of six employers, six employees and a chairman. ${ }^{3}$ The coal owners were not interested in arbitration and Mundella refused to intervene until they were. Early in May, when both parties and the civic authority were exhausted the employers agreed to arbitration and, with Mundella's help, an agreement was reached. The reduction the employers wanted at the beginning of the strike, namely is per cent, was enforced, but there was to be no victimization. It was also

1 Transactions of the National Association for the Promotion of Social Science, $\mathrm{r} 868, \mathrm{p}$. 577.

2 The Times, and May, I 868.

5 Ibid., i 8 th April I 868. 
agreed that "as soon as the strike is at an end, the agitation subsided, the employers will seriously take into consideration the practicability of establishing a Board of Arbitration and Conciliation". ${ }^{1}$ The workers returned to work but no board was established; their only gain from the intervention was the assurance that there would be no victimization. Elsewhere in the coal industry there was no economic reason to compel coal owners to accept arbitration. In South Derbyshire a lockout lasted for more than a year because the employers refused to submit their case to arbitration. ${ }^{2}$

A few employers were converted to the idea of conciliation irrespective of economic conditions. One such man was David Dale, the Darlington ironmaster. Dale attended meetings of the Associated Chamber of Commerce from 1865 at which he heard papers read on conciliation boards. He was particularly impressed by Mundella's contribution and decided that a board might be useful in the iron trade. ${ }^{3}$ In March I 867, Dale circularized each member of the Iron Manufacturers' Association with a letter asking them to consider the formation of a "Standing Local Committee" of employers and men to discuss "questions affecting their mutual relations", but most were not interested. ${ }^{4}$ John Kane, the general secretary of the Association of Ironworkers, had pressed for arbitration during a six month lock-out in 1866 but the employers had refused. And in December, 1867 , they had turned down his request for a general conference of employers and workers. The American demand for rails was low in those years and the price of rolled bars was falling. The employers were in a position to enforce wage reductions in 1866 and virtually to destroy the three year old Association of Ironworkers. In 1869 the demand for iron increased, the level of employment rose, and employers faced the prospect of demands for wage increases with the possibility of strikes if they were not conceded. In this situation, on 22nd March, I 869, the Board of Arbitration and Conciliation for the Manufactured Iron Trade of the North of England was formed.

The ironmasters not only wanted to avoid strikes because of prosperity they saw ahead, but they wanted to avoid strikes because of their high cost to them. The iron industry was highly capitalized and even short strikes were expensive. The coal industry was in a wholly different position. Apart from the problem of keeping the pits clear

1 Ibid., 5th May I 868.

2 Ibid., I6th March, I 868; also J. E. Williams, The Derbyshire Miners, pp. I I 5-1 I7.

${ }^{3}$ Cf. A. J. Odber, The Origins of Industrial Peace: The Manufactured Iron Trade of the North of England, in: Oxford Economic Papers, vol. 3, No. 2, June 1951.

4 Ibid., p. 207. 
of water strike action involved little technical cost so there was no incentive to avoid strikes on this score. Because coal stocks were bulky coal owners sometimes welcomed strikes as a means of clearing them away, and, in the process, of forcing coal prices up. Wages fluctuated considerably. Labour costs were dominant in total costs so employers endeavoured to reduce them immediately the market situation changed adversely for them, but because they found it relatively simple to pass increasing costs on to consumers during a period of prosperity, partly because they faced relatively little foreign competition, they did not then strongly resist demands for wage increases. The coalfields, however, differed from each other in the ease of coal-getting, in their market situations and in their labour requirements and the owners in them reacted differently to union and external pressures for conciliation and arbitration boards.

A. J. Mundella believed that the coal-owners should have established boards in 1869 when trade was bad. "My only desire", he wrote, "is that employers will have the sense to adopt what is good in my plan and to seize the present state of trade as a favourable opportunity of doing it; otherwise I fear, when trade revives, they will reap the bitter fruits of their present obstinacy and folly... I fear Normansell and all his societies will be involved in temporary ruin, and when prosperity returns they will not be in so tractable a frame of mind as at present." The coal-owners did not seize the opportunity. The unions in any event were weak at that time. In addition the union leaders did not change their minds about the boards; they consistently advocated them through good and bad trade. During the coal boom years from $187 \mathrm{I}$ to 1874 the unions expanded and accumulated funds which some of the leaders wanted to preserve at all costs. John Normansell of the South Yorkshire Miners, Thomas Burt of the Northumberland Miners and William Crawford of the Durham Miners' Association knew sufficient about the impact of boards to realize that they reduced the incidence of official strike action, and there, the financial responsibilities of unions.

All of the prominent union leaders in the mines supported conciliation and arbitration but, depending on the coalfields they operated in, they faced two types of reaction from employers. The owners in the old established fields of Northumberland and Durham formed joint committees to discuss local matters but preferred to refer disputes to arbitration on an ad boc basis. ${ }^{2}$ A permanent board was formed in

${ }^{1}$ Quoted by Williams, op. cit., p. I40.

2 Cf. E. Welbourne, The Miners' Unions of Northumberland and Durham. After the strike against the yearly bond in 1869 in Durham there were no large strikes or lockouts which officially involved the unions in Northumberland and Durham until the late 1870 os. 
South Yorkshire but here too as well as in West Yorkshire single arbitrators were used. ${ }^{1}$ On the other side of the Pennines, in Lancashire, North Wales, South Wales and South Staffordshire, the coalowners refused to form joint committees and bitterly opposed arbitration of any form. The South Wales coal-owners considered it was one-sided and favoured the men; in addition they disliked it because it involved acceptance of trade unions. Towards the end of 1874 and in 1875 the owners in these fields accepted arbitration but then only after long and bitter disputes. The Scottish coal-owners had one conference with the miners' representatives in 1873 and then did not meet again until the end of the century. ${ }^{2}$ The South West Lancashire coal-owners rejected arbitration because they did not believe their disputes should "be settled by men with no interest in the trade". ${ }^{3}$ In South Staffordshire a strike against a wage cut lasted for I6 weeks before the owners were prevailed upon to accept the mediation of the Mayor of Birmingham, Joseph Chamberlain. The Amalgamated Association of Miners which organized the miners in these fields adopted a policy of arbitration in all cases where employers sought wage cuts in 1874 but promised support should arbitration be refused. ${ }^{4}$ The intensity of the employers' reaction can be seen from the fact that during 1873,1874 and 1875 the union was virtually destroyed by the constant strain of strikes and lock-outs. ${ }^{5}$

\footnotetext{
1 South Yorkshire had more troubles than the north east coalfields. Neither the miners nor the coal-owners operated arbitration so consistently and in 1874 there was a lock-out of 23,000 miners over a wage reduction. But even so, Yorkshire was an area of industrial peace compared with the coalfields on the other side of the Pennines.

${ }^{2}$ R. Page Arnot, A History of the Scottish Miners, p. 54.

${ }^{3}$ Capital and Labour, 8th April, i 874 .

4 Capital and Labour, I ith March I 874, p. 39.

5 Cf. G. D. H. Cole, Some Notes on British Trade Unionism in the Third Quarter of the Nineteenth Century, in: International Review for Social History, vol. II, 1937, Pp. I-23. In addition to a large number of local strikes, the Amalgamated Association of Miners was rarely left without a major strike or lock-out to finance. It grew out of a 6 weeks' strike in South Lancashire in 1868 . (The Times, I6th March I 868 and various dates till sth May I 868). A I 3 months' strike for union recognition in Burnley was a constant drain. (The Times, 8th October, I873; Capital and Labour, 6th May, 1874, p. 229 and 26th August 1874, p. 61 2). In 1873 there was a lockout for 3 months in South Wales (The Times for various dates between 7 th January 1873 and 19 th March 1873 ). In the same year there was a lock-out in North Warwickshire (The Times $7^{\text {th }}$ January I873). In 1874 there was a 4 months' strike in South Staffordshire (The Times, I I th July I 874), a 7 weeks' strike in South West Lancashire (The Times, 6th October, I 874 and roth November 1874), and a 7 weeks' strike in the Forest of Dean ('The Times, Ist January 1875). 1875 was dominated by a 5 months' strike in South Wales (The Times, 29th December, 1874 ; 2nd January, I875 and various dates to 28th and 29th May, 1875). By the summer of 1875 the union was virtually insolvent. It merged with the Miners' National Association in August, 1875 .
} 
The workers who were convinced by the eloquence and reasonableness of the middle class intellectual advocates of conciliation and arbitration to act moderately during a rising market were quickly disillusioned when trade began to slacken off and employers wanted wage cuts. Conciliation worked only where the union leaders were willing to endorse the wage reductions suggested by employers and then it was only operative at the top negotiating level. William Crawford who accepted a wage reduction of $10 \%$ for the Durham miners in May, 1874, had to contend with unofficial strikes by colliery mechanics. ${ }^{1}$ When, early in 1874 , the Scottish coal-owners demanded a wage reduction of $20 \%$ Alexander Macdonald advised the miners to accept it. There were vociferous protests. ${ }^{2}$ Unofficial strikes were frequently called against adverse arbitration awards; indeed this period saw the beginning of unofficial strike action. When in October, 1875 , an arbitration award granted the North Wales coal-owners the reduction of $15 \%$ they demanded, the miners struck work and submitted a demand for a $20 \%$ wage increase. ${ }^{3}$ A breakaway union of colliery mechanics was formed in the Northumberland coalfield because of an adverse award in April, i 875. The depression after I 873 broke down effective conciliation and arbitration in the Nottingham lace trade. "The capitulation of the Levers Lace Trade Society in the face of repeated reductions resulted in the formation of a breakaway union resolved to ignore the decisions of the Board of Arbitration." 4 Later, in December, I873, the whole of the union struck against a wage award. Mundella's hosiery board met serious difficulties as early as 187 I when an unpopular award caused a rift between the handframe workers and machine operatives. ${ }^{5}$ No industry which used arbitration was able to use it successfully to enforce wage cuts. The North of England Arbitration Board had to contend with unofficial strikes in 1875 . The Board fined the puddlers at a Stockton works for taking unofficial action in April, I $875 ;^{6}$ on other occasions strikers were simply admonished. The strikes were accompanied by the denigration of union officials associated with the Board.

Where employers could not get the wage reductions they required

${ }^{1}$ E. Welbourne, The Miners' Unions of Northumberland and Durham, p. 160.

2 A. J. Youngson Brown, Trade Union Policy in the Scots Coalfields, 1855-1885, in:

Economic History Review, vol. VI, No. I, 1958, pp. 42-44.

${ }^{3}$ Capital and Labour, I3th October 1875.

4 Cuthbert, op.cit., p. 45.

${ }^{5}$ Church, op.cit., p. 58.

6 Capital and Labour, sth May, 1875, p. 195. 
they submitted successive demands. For instance in February, 1874, the Oldham and Ashton-under-Lyme coal-owners asked for a I $5 \%$ wage reduction and were awarded 10\%. The next month the employers gave notice of a further $5 \%$ decrease. ${ }^{1}$ Arbitration did not noticeably slow down the tempo of wage reductions. Coal owners in Somerset asked for 10 per cent wage reduction in April, I 874; the workers asked for arbitration and while this was pending the employed demanded another is per cent reduction. The arbitrator, Judge Kettle, awarded a $23 \frac{1}{2}$ per cent reduction. ${ }^{2}$ When arbitration acted as an obstruction it was side-tracked. Thus the Hosiery Board was completely inactive for about 3 years following the breakdown of trade due to the American civil war. It was as R. Fothergill, M.P., the chairman of the South Wales Coal-owners Association, stated before the long lock-out in 1875 , that "no arbitrator could say that a master should carry on his business at a loss". 3

\section{CONSEQUENCES FOR TRADE UNIONS}

The development of conciliation and arbitration had important consequences for trade unionism. Mundella's Hosiery Board was concerned with conciliation. The chairman of the Board, which had an equal number of representatives from each side of industry, had a casting vote but it was rarely used. Mundella was the chairman until i 870 and as it was considered undesirable for an employer to have the decisive vote in case of deadlock the Board's constitution was changed to give the casting vote to an independent referee. ${ }^{4}$ The Nottingham Lace Board which was largely modelled on the Hosiery Board provided for the use of an independent referee from the outset. ${ }^{5}$ The boards set up by Judge Kettle were essentially arbitration boards. They could conciliate but they specifically provided for decision-making by an umpire and his decision was binding on the parties.

There was much discussion at the Royal Commission on Trade Unions and at the meetings of the National Association for the Advancement of Social Science about the relative merits of the types.

1 Ibid., 4th March, I 874 , p. 85 .

2 Ibid., 6th May, 1874, p. 224.

${ }^{3}$ Ibid., I $7^{\text {th }}$ March, 1875 , p. 55 . A similar view was expressed by Thomas Ellison, Judge of the Sheffield County Court, in 1879 when he arbitrated in a Yorkshire mining dispute. He awarded that wages should not be reduced, "provided always that this award is not intended, and shall not be construed, to restrict or in any way interfere with the right of the owners to close at their discretion all or any of the collieries within the said area..." (Williams, op.cit., p. I63).

${ }^{4}$ Church, op.cit., p. 58 , and Crompton, op.cit., p. 37.

5 Cuthbert, op.cit., p. 43. 
Opinion favoured conciliation but it was Kettle's system which spread. By the early I870s many disputes were decided upon by referring them to independent arbitrators. The practice in the North Eastern coalfields was to appoint two arbitrators or assessors from each side and an independent umpire. When trade unionists voted for arbitration, as they did in all the miners' unions at various times, and when the employers resisted it on the grounds that outsiders should not interfere, arbitration meant decision-making by a person not connected with the industry.

When unions and employers opposed each other in strikes or lockouts each side had its own criteria for deciding what amounts should or should not be accepted or granted but they were not discussed and a compromise could in fact be reached by using two entirely different criteria. Once conciliation was practised, the criteria had to be made explicit, though even here amounts could be agreed upon without reference to standards. Arguments about criteria on conciliation boards did take place but the real discussion occurred in arbitration cases for single arbitrators had to discover criteria which were acceptable to both sides. This discussion took place in public.

The question was by what standard should wages move up and down? According to changes in the cost of living? Changes in the level of profits, costs of production, selling prices and if so at what point of production, or according to the inexorable laws of supply and demand? The discussion was conducted by intellectual arbitrators with contributions from both sides, though the contribution from the unions was strongly influenced by the views of the arbitrators themselves. The discussion was hampered by a lack of statistics concerning costs and profits. There was rank and file trade union pressure for the criterion to be the cost of living or a "reasonable minimum of comfort". In March 1874 a public meeting of engineers, smiths, and boilermakers complained that "the present rate of wages is not commensurable with the expenditure of living..." 1 The Durham miners in 1874, contended in an arbitration case before Russell Gurney, the recorder of London, that wages should provide a "reasonable minimum of comfort" but the coal-owners refused to admit that the high cost of living was a valid reason for withstanding a wage reduction. ${ }^{2}$ The employers, too, refused to allow profits to be

${ }^{1}$ Capital and Labour, I8th March, 1874, p. 63.

2 Welbourne, op.cit, p. 166 . When Thomas Ellison made his award in the 1879 Yorkshire mining dispute he admitted "that the wages now received by the miners are barely sufficient to afford a decent maintenance of themselves and families" and awarded accordingly. He went on, however, to concede to the employers the right to break the award if it proved too costly (Williams, op.cit., p. I63). 
regarded as the standard; in any event they kept quiet about their profits. They used rising costs to justify a wage reduction, ${ }^{1}$ but refused to allow costs to be a consistent criterion. The only standard the employers allowed was the movement of selling prices.

Other sections of the industry went through similar experiences so that by 1875 wages were by and large determined by movements of selling prices. The Board of Arbitration and Conciliation for ironworkers in Staffordshire fixed wages according to the selling price of bar iron. The question then arose that if there was a ready made criterion for determining wages then arbitration was not only costly, it was unnecessary. An arbitrator in a Durham coal dispute made this point in 1876 when he said he hoped "some self-adjusting principle may be discovered for regulating wages, one more simple, ready and less expensive than arbitration".2 A sliding scale agreement which related wages to selling prices and which considered the subsistence aspect of wages only by containing upper and lower limits was accepted by iron workers early in 1875 . Later, similar agreements became common in the coalfields.

The consequence for trade unionism was that with an automatic means of regulating wages, trade unions became, or so it seemed at the time, largely unnecessary. After the introduction of the sliding scale in the South Wales coalfield, trade unionism died for about 2 decades; in the Forest of Dean miners simply contracted out of the union because they thought it was unnecessary. The introduction of sliding scale agreements was one of the factors which caused the membership of the Association of Ironworkers to decline from 35,000 in 1873 to 1,400 in 1879 .

\section{CONCLUSION}

In conclusion, formal arbitration and conciliation machinery, then sliding scale agreements, occurred in the newly expanding industries. The traditional crafts were largely governed by working rules and regulations on which the unions permitted no scope for arbitration. Neither the Operative Stonemasons' Society nor the Boiler Makers Society, for instance, would countenance arbitration. And it was only on occasions that arbitration occurred in the engineering industry. It was not possible, moreover, in many crafts to find a simple and acceptable criterion for determining wages; certainly selling prices could not always be used. Also the crafts were often dominated by

\footnotetext{
${ }^{1}$ For example coal-owners considered that miners should bear part of the cost of administering the 1872 Mines Regulation Act.

2 Capital and Labour, 23 td February, i 876 . p. I 40.
} 
employers who were difficult to organize. In Sheffield, for example, the industrial structure was dominated by many anachronistic features. The employers ranged from small masters to large integrated jointstock companies and it was difficult to achieve cohesion among them. Local arbitration boards were proposed by the Sheffield engineering unions in $1867,1875,1883,1887$, but, despite the active interest of the Sheffield M.P., A. J. Mundella, the proposals all came to nothing. ${ }^{1}$ Where conciliation and arbitration were employed and were succeeded by sliding scale agreements, trade unionism was contained and disarmed at a significant stage of its growth. To this extent the advocates of the formal institutional treatment of industrial disputes succeeded where the document, lockouts and repressive legislation had failed.

1 Sidney Pollard, History of Labour in Sheffield, p. 134. 